\title{
THE CREATION OF DEVELOPMENT REGIONS AS INPUT TO THE REGIONAL DEVELOPMENT IN THE NORTH-EAST WILAYAS (DEPARTMENTS) OF ALGERIA
}

\author{
Fethi NACER * \\ Doctorant, Institute of Earth Sciences and Universe, University of Batna 2, Algeria \\ e-mail: f.nacer@univ-batna2.dz \\ Hadda DRIDI \\ Pr. Laboratory LRNAT Institute of Earth Sciences and Universe, University of Batna 2, Algeria \\ e-mail: hadda.dridi@gmail.com
}

Citation: Nacer, F., \& Dridi, H. (2021). The Creation of Development Regions as Input to the Regional Development in the North-East Wilayas (Departments) of Algeria. Analele Universităţii din Oradea, Seria Geografie, 31(1), 1-10. https://doi.org/10.30892/auog.311101-852

\begin{abstract}
The research paper aims to create development region, as itis a means for reorganizing the potential for development, as the research work dealt with a systematic vision based on the merging of the results of statistical analysis with the principles adopted in regional divisions, we have identified three regions with different developmental characteristics; the north eastern developmental region, the Constantine development region and the eastern high plains region. The results of the work are shown in a map of development regions were the final outputs of the research paper are prepared.
\end{abstract}

Key words: Region, Development, Development Region, Factor Analysis, cluster Analysis

$$
* \quad * \quad * \quad * \quad * \quad *
$$

\section{INTRODUCTION}

The most significant feature in the current economic politics in many developing countries is the increasing focus on resolving the regional issues for an economic and social development, and the promotion of the underdeveloped region's economies through the achievement of some degree of economic efficiency and better utilization of natural resources beside improving its economic integration with the developed regions. Furthermore, the diversification of their activities, allowing access to real regional development.

Region and regionalization are the most commonly used concepts in geography especially in regional geography. These terms are frequent in academic literature as well as in economy and international affairs where in the major concern is the division of the overall range for the spatial variations into regions and to look into the appropriate bases and criteria for the division process (Richard, 2014; Herman et al., 2016, 2018a,b). Thus, the regional field must be the ground for control 
and adjustment based on consultation on development strategies (MEAT, 1995). In order to carry out the division process in an acceptable manner, it is imperative to understand the fundamental characteristics, which attribute to one region its distinction, region are geographically united subdivisions of alarger are a characterized defintive criteria or fromes of reference (Kovaçi et al., 2020).

Like other developing countries, Algeria after regaining its political independence is striving to establish the developmental balance between the different territories so that it can overcome the problems that permeate all areas of life as cities overcrowding and housing crises. Addition, the lack of efficiency and inadequacy of services destined for the general public alongside with the concentration of natural, economic and social potential in some regions and not others. The issue of the search for a balanced regional administrative structure and the accompanying effort to alleviate developmental imbalances between the Algerian regions was and is the main subject. The Algerian state's interest in regional balance policy dates back to the beginning of 1966 with the birth of the first national plan in 1967, local processing programs in 1970 In addition to the applications of the agricultural revolution in 1973 aiming to reduce developmental imbalances and promote the economies of underdeveloped regions. This issue was also addressed in numerous national charters (1964-1976) as it was included in many scientific gatherings and in political speeches of Algerian officials who stressed the need to address the issue of development imbalances by implementing a regional structure that meets all of the population needs and restores the development balance between all the Algerian regions.

Based on this concern, the Algerian authorities have innovated many administrative divisions (1963-1984-1974) wherein the wilayas are considered as planning territories and by the end of the 1980s this focus was materialized with the development of a strategy for the reorganization of the Algerian sphere; this work resulted in the enactment of the act (loin $\mathrm{n}^{\circ}$ 03-87) a law defining the implentation framework for aterritory planning policy. The drafted act provided for the division of the national sphere into planning regions. According to article 41 which determines the conditions for the assembly of contiguous wilayas, which are characterized by a common morphology and prepare the region with a scheme included in the regional plan for the urban development.

The various actions aiming at the creation of development regions in Algeria have proved to be unsuccessful since the poverty map, completed by the National Territorial Planning Agency in July 2005 confirmed the expansion of poor municipalities in Algeria. Also, In a 2012 a study carried by the Algerian News Agency, shows the deficit of 1200 municipalities from the total of 1541 municipalities and as migration between regions continues also the divisions are confined to the development situation without consideration to the institutional part in other words the absence of genuine regional administrative institutions representing the regions; All are manifestations and reasons that shed light on the ineffectiveness of the work of the regional divisions that have been completed, in fact, this issue has many justifications, of which the most important are:

- The approved administrative and geographical criteria do not conform to the development needs to be achieved in the country, and the economic and social reality is not in any way compatible with the results of the emerging division.

- The nature of the Algerian economy, its instability and its dependence on the scoop profit have increased the problem of development imbalances by focusing on some regions alone.

- Administrative decentralization applied in Algeria is essentially formal, many local decisions come from the central authority. We further stress the futility of regional divisions with the practical state of the approved administrative decentralization, with our prior knowledge of the difference between decentralization and regionalism.

- The instruments for field analysis and diagnosis are the basis for regional division adopted were not highly relevant in creating spatial entities consistent with the stated development needs and objectives.

Considering the last justification, the research work to be accomplished suggests the creation of development regions, according to a research methodology based on scientific information and facts on account ofthe research has a classification objective in creating development territories that are an alternative to those used in Algeria. In addition, this paper provides solutions to various existing or potential emerging economic and social problems and a new work approach with regard to regional divisions. 


\section{METHODOLOGY}

To achieve the research goals, the researcher used the Ministry of Finance data for 2016 through the section on general statistics, further to consulting the sources of information available from previous studies and reports on the subject. The researcher has relied on quantitative descriptive approaches to collect a plethora of the characteristics and specifications of the studied phenomenon which assisted to identify the most relevant indicators, especially pointers related to the agricultural and industrial aspect, as well as indicators related to the equipment and services aspect.

The researcher has utilized statistical analysis to facilitate the use and statistical processing of variables and analyze the results and extracting the homogeneous, developmental groups from the total wilayas furthermore to project the principles and foundations applied in the division of territory and the extraction of development territories as demonstrated in (Figure 1) which describe the method for extracting territories adopted by the investigator. For data analysis, the researcher used the Statistical Program (SPSS), a widely utilized and most appropriate program for such subjects: homogeneous groups are established statistically using many indicators and in group acquisition and processing through statistical methods, general analysis and cluster analysis (Othman, 1998). Many statistical researchers have used statistical analysis approaches to the interpretation of variability, in an attempt to classify phenomena with spatial dimensions, we mention (Amer, 2000) who, has used the general analysis curriculum to analyze the disparities in services for the Arab State of Egypt.

Also, in a study by (Vučković et al., 2018), using the (SPSS) program and the statistical analysis approach, he identified social characteristics as factors challenging economic development in the province of Kolubara, Republic of Serbia (Lekhal, 1996). Also used in his study of the Algerian the Methode of basic component, in order to be able to use statistical analysis method, lessons (Kolladi, 1993) were used in data analysis, study (Laffly, 2000) which is an introduction to factor analysis was Revewed in order to reach scientific approach to the subject of regional divisions and benefited from, incluing a study of (Benmammar, 2003).

Regional divisions are based on the principle of spatial homogeneity so in order to attain it andreah the objectives of research, the results of statistical analysis have been integrated through homogenous, developmentally and statistically groups derived from the statistical program, while projecting the principles and foundations that enable us to develop a development region seeing regions are spatial entities directly under the State level that have political representation to ensure their existence (Mechiche, 1997). This method facilitates having fewer groups than wilayas, which are embodied in statistically and spatially homogeneous territories, therefore each state has its own developmental character. The research paper results are identified in the map of development regions. Accordingly, the bases and principles used in the division into regions are carefully selected to conform to the geographical, social and economic reality of Algeria, namely:

- To take in consideration the geographical, economic and social homogeneity of the country as possible.

- To consider the current division of wilayas.

- To account the economic integration in some wilayas as possible (Annaba-Tebassa).

- To provide as much possible an economic base and a bank for each region.

- Natural and social problems unity so that we can develop policies and strategies that address the problems in a coherent manner.

- The creation of an urbanism beacon center in each region to promote the social and economic life of the population.

- Adequate space is required to meet urban growth requirements, especially in urban areas.

- To take the statistical analysis results adopted in the study under advisement.

We emphasize that regional division is evolving and changing as the social and environmental aspects are becoming increasingly important day by day This reason why we choose the dividing criteria related to the spatial and temporal reality of the unit studied. Besides, The results and the extent of the regional divisions are also linked to the importance of developments and changes in modern analytical techniques and methods used for this purpose. 
The importance of the method used in the development of the Territories lies in the integration of statistical analysis results (factor analysis, meta-analysis). Along with the foundations and principles of zoning, these principles have been carefully selected to be consistent with the reality and circumstances of the State. Hence, the integration method used in the development of regions is linked to the modification and correction of the statistical analysis results so that they be consistent with the definition of the Region. The statistical analysis section of the method used for numerous research works is therefore used, some have already been mentioned. Indeed, the new angle in this approach is to project the principles and foundations of division on the previous results and to consider the results of statistical analysis as the basis for the division process as illustrated by the principles adopted. The steps of the method are reflected in the following figure.

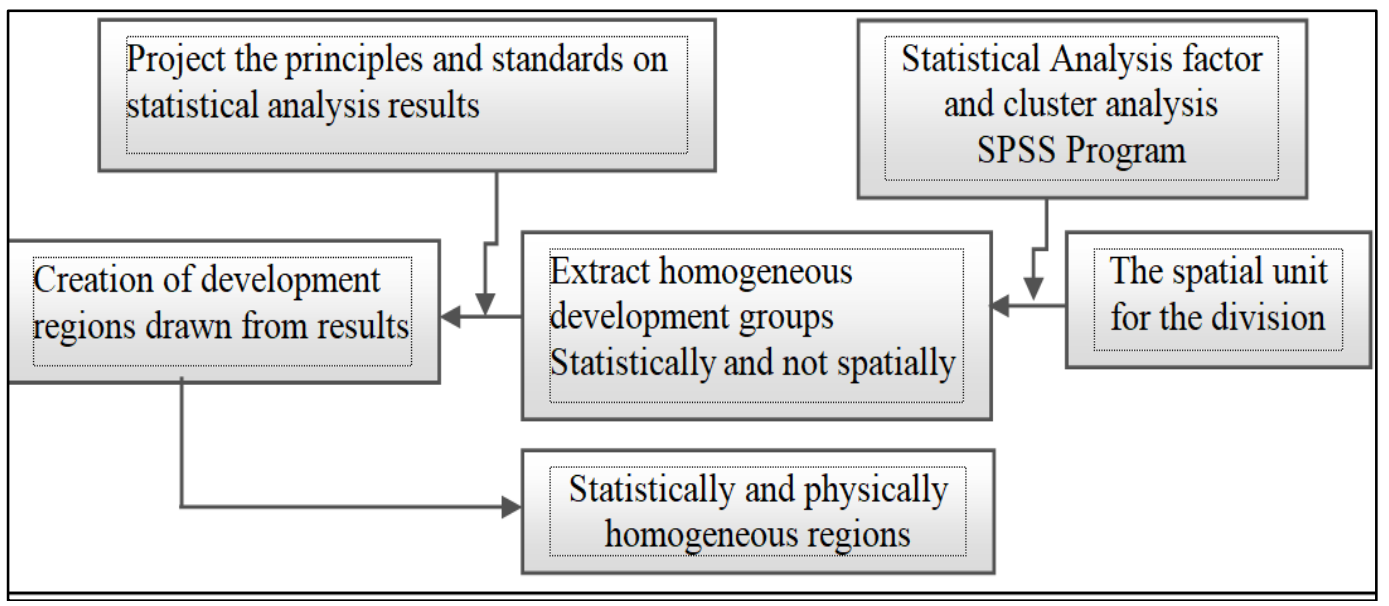

Figure 1. The integrated method of developing regions Source: NACER Fethi

\section{DESCRIPTION OF THE STUDY AREA}

The study area is located in the northeast of Algeria within an area of $92822 \mathrm{~km}^{2}$ consisting of 15 wilayas according to the administrative division of 1984 , topographically the area is composed from two groups:

The first group lays in the north, with the Tell mountains that are created from two overlapping chains, so called the Tell group, Lowlands are limited, some overlook the coast and are called coastal plains, others are hinterlands called Endorheicbasins, the most important low-lying areas (Annaba plain, Skikda plain, Guelma basin, TeleghmaBbasin, Tamlouka basin) where the bioclimatic area rages from humid climate in the coast to semi-humid in the south, the group extends over a 430-kilometers of seaboard, the wilayas that are expressive of this area are (Annaba, El Taref, Skikda, Mila, Souk Ahras, Guelma, Northern Setif, Jijel, Northern El Bordj and Constantine).

The second group is located in the south of the first one; wide and more openly formed from plains, wide on top that appear in a fashion of lengthy corridor adjoined in the north by southern foothills of the Tell Atlas the vast plains are enclosed by humid spaces called Sebkhahs (marshes). The bio-climatic range of the group is predominantly a semi-dry climate, the wilayas that are most expressive of this area are: (Tebessa, Oum el Bouaghi, Southern Setif, Khenshla, Batna, El Msila).

The study area is dominated by the Mediterranean climate but it is gradually deteriorating as we move south from the humid to the desert range. So, in terms of climate potential, it is in the interest of the Tell group but as regards the terrain potentials, the upper plains are more favorable. This terrain duality of was a natural obstacle to the study area, especially with the agricultural potential that becomes scarce under natural handicap and figure 2 illustrates the localization of the study area. 


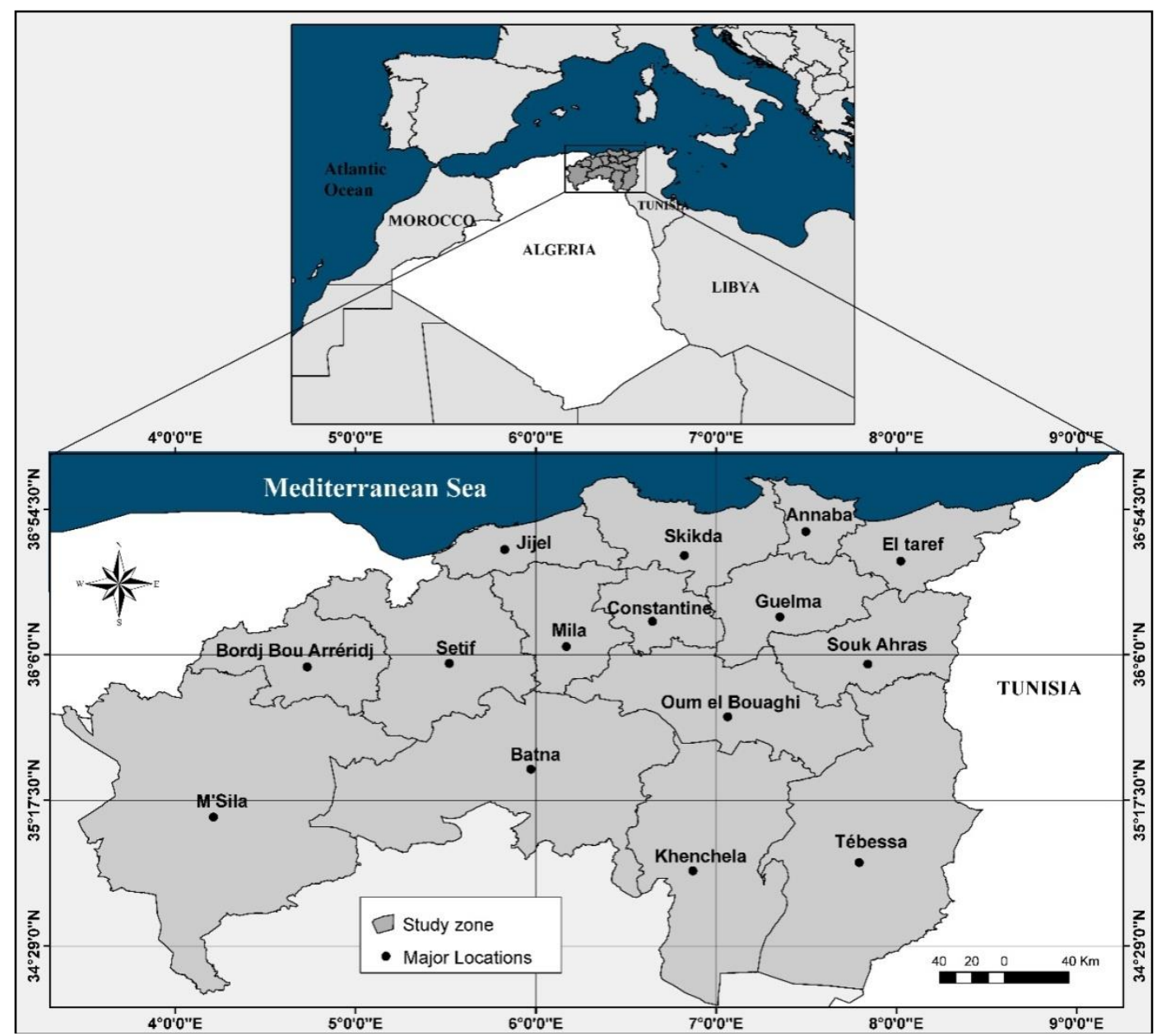

Figure 2. Localization of the study area Source: NACER Fethi

\section{RESULTS AND DISCUSSION}

Based on the paper's objective, and in compliance with the methodology through applying SPSS program and drew on the work's approach, In the first stage, we identified homogeneous, developmental groups. In the first phase, we identified developmentally homogeneous, groups by the means of applying the statistic factor analysis through employing the basic components method as well as the statistic meta-analysis engaging (k.Means cluster) logarithm. To project, in another phase, we have projected the principles of regional division consequently we have established the map for the Regional Development, which is the goal to be achieved.

\section{Results of the factor analsis}

The outcomes of the factor analysis for the response variables to the hidden official factors are estimated at 3 key factors. The most relevant ones are the first, second, and third factors, as they constitute $58 \%$ of the existing variations. For that the first factor was estimated at $29.17 \%$ and the second factor at $15.66 \%$ and the third factor at $13.91 \%$ for the correlation matrix. The first factor is considered as the largest ratio in the variation structure of response variables, then the second factor, and so on. The correlation matrix and the results of the practical analysis obtained were used in accordance with the following analysis: 
- Factor one, comprehensive development: The nature of the variables and their relation to the first factor are wide-ranging between navigation, industry and service equipment for instance, the variable of treatment rooms is estimated at 0.815 , the industrial sector variable (industrial zone surface), associated with the first factor is estimated at 0.780 , whereas The service sector variable is estimated at 0.717 . The service sector variable is estimated at 0.717 .

- Second Factor, Industrial Development and Service Equipment: The factors most relevant to the second one are the variables for the industrial sector, which are estimated at 0.658 , the service sector variable is estimated at 0.717 .

- Factor three, Agricultural Development and Service Equipment: The program shows that there is a strong correlation between the total agricultural area and factor 3 with a factor of 0.727 , the variable for the service-equipment sector is the factor associated with a capacity of 0.673 .

\section{Results of the cluster analysis}

By applying SPSS program and using the location for analysis using the logarithm of (K.Means Cluster) four major groups were found, thus identifying the homogeneous, developmental groups, which are as follows:

- The first group: It comprises one wilaya (Setif), completely separate from the other groups, its developmental character is reflected in its being an (agricultural-industrial)wilaya, as formalized by the program.

- The second group includes five wilayas (Oum El Bouaghi, Batna, Tebessa, Mila and Annaba), and according to the results of the analysis, these wilayas have a distinctive developmental nature (agricultural - service equipment).

- The third group included one wilaya, Constantine, and according to the results of the analysis, it is a state of an (industrial - service equipment) nature. The group is characterized by an increase insome variables value and a significant decrease in the others, Constantine city includes the largest population in the eastern Algerian region (1995 MEAT) after Algiers and Oran.

- The Forth Group: The group comprises the largest number of wilayas (Guelma, Souk Ahras, Khenshla, Msila, BourdjBouAriridj, Jijel, Skikda and El-Tarf). These wilayas are characterized by comprehensive developmental nature (agricultural, industrial, equipment and services). Note to be retained on this group : many wilayas were created with the administrative division of 1984, and many of their indicators still need development support to reach national development rates.

\section{Development Regions of the Algerian North-East wilayas}

According to the correlated method related to the results of the factor as well as metaanalysis and to the application of the criteria and principles selected for the regional division and in conformity with the development reality of Algeria, we identified three key positive regions. The results of the method adopted in the search established distinctive regions nevertheless that are, spatially, economically and socially homogeneous. More importantly, each region is characterized by a developmental diversity and by various activities that underpin regional integration, and comprehensive development which is a goal that we aim, monitored by the State, harnessing all the potential to achieve. The output of our research is highlighted in the final map, of the development regions since the division principles have been taken into account in order to give the necessary spatial harmony. The integration has resulted into three regions with five wilayas each, and every single region has a diversity of development specificities, which has been added to the results of the factor in addition to meta-analysis analysis. The Research work emphasizes the existence of homogeneous and diverse developmental regions, and the output of the research paper is highlighted on the map shown in (Figure 3), with the presentation of a specific analysis of the innovated regions, as follows:

- The Extreme North-East Developmental Region: The region consists of five states (Annaba, El Taref, Souk Ahras, Guelma, Tebessa), characterized by diverse economic activities with two states (Annaba, Tebessa) specialized in agriculture and service facilities, in terms of a developmental 
activity while the rest of the states (Guelma, El Taref and Souk Ahras) are typified by a developmental diversity from agriculture, industry to service facilities.

- Constantine Developmental region: This region consists of (Constantine, Mila, Jijel, Oum El Bouaghi, Skikda). Activities vary in this region, where Constantine particularly distinguished by the industry and service facilities. Whereas the two wilayas, (Mila Oum El Bouaghi), are specialized in agricultural activity along with service facilities, moreover the states of Skikda, Jijel, are characterized by diversified activity amongst industrial agricultural and service facilities.

- Development Region of the Eastern Upper Plains: In this region, most states are located within the upper eastern plains, counting five states (BatnaSetif, BourdjBouAreridj, Khenshla, Msila), typified by a diverse range of activities.: the wilaya of Setif is distinguished by agriculture and industry, Batna is typified by agricultural activity and service facilities, and the rest of the wilayas (BourdjBouAreridj, Msila and Khenshla) are characterized by a variety activities , agricultural, industrial, equipment and services.

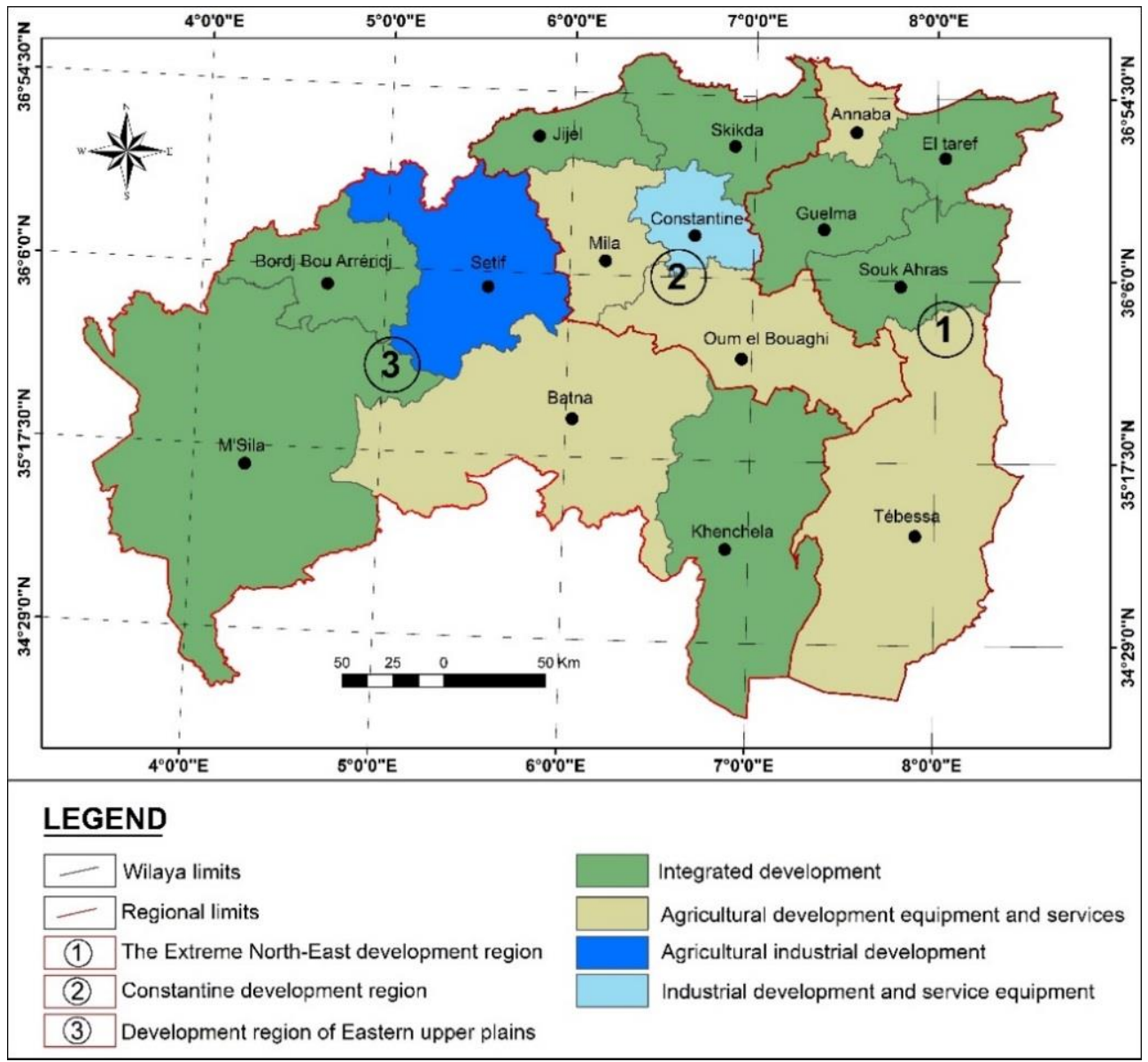

Figure 3. Development Regions of the Algerian North-East wilayas Source: NACER Fethi

\section{Characteristics and Potentials of the Created Development Regions}

Research work output was represented in the innovated regions, considered as spatial entities located directly below the State level defined by administrative boundaries that render them geographically, demographically, economically distinct. As they possess natural ingredients that 
qualify these regions to attain more progress. The subject matter potentials are also perceived as important strategic stakes for the population. According to the information exhibited on the table, each region has relative particularities that distinguish it, besides this table describes the characteristics and qualifications of each region through some quantitative and descriptive variables:

Table 1. Characteristics and Potentials of Developmental regions in the North-East Algerian wilayas

(ONS - SNAT)

\begin{tabular}{|c|c|c|c|c|c|c|c|c|c|}
\hline \multicolumn{8}{|c|}{ Characteristics and Potentials } & \multirow{3}{*}{$\begin{array}{l}\text { Consisting } \\
\text { Wilayas }\end{array}$} & \multirow[b]{3}{*}{ Regions } \\
\hline \multirow[b]{2}{*}{$\begin{array}{l}\text { Une } \\
\text { mplo } \\
\text { ymen } \\
\text { t rate }\end{array}$} & \multirow[b]{2}{*}{$\begin{array}{l}\text { Regionl } \\
\text { cities }\end{array}$} & \multirow[b]{2}{*}{$\begin{array}{c}\text { Seacoat/ } \\
\mathrm{km}\end{array}$} & \multirow[b]{2}{*}{$\begin{array}{l}\text { Populat } \\
\text { ion } \\
\text { Densitb } \\
/ \mathrm{km}^{2}\end{array}$} & \multirow[b]{2}{*}{$\begin{array}{l}\text { Growth } \\
\text { rate } \%\end{array}$} & \multirow{2}{*}{$\begin{array}{c}\text { Populat } \\
\text { ion size } \\
- \\
\text { inhabita } \\
\text { nts } \\
\end{array}$} & \multicolumn{2}{|c|}{ Natural characteristics } & & \\
\hline & & & & & & $\begin{array}{c}\text { Physical } \\
\text { Characteristics }\end{array}$ & $\begin{array}{c}\text { Climate } \\
\text { characteristics }\end{array}$ & & \\
\hline 40 & Annanba & $\begin{array}{c}\text { (Annaba } \\
- \text { El } \\
\text { Taref) } \\
170 \\
\end{array}$ & 161 & 1,41 & $\begin{array}{c}280421 \\
9\end{array}$ & $\begin{array}{c}\text { Diverse } \\
\text { topographical } \\
\text { region } \\
\text { predominantly } \\
\text { Tell mountains } \\
\end{array}$ & $\begin{array}{l}\text { Diverse Bio- } \\
\text { climatic } \\
\text { region } \\
\text { (Humid- } \\
\text { Sub-humid) } \\
\end{array}$ & $\begin{array}{c}\text { Annaba-El } \\
\text { Taref-Guelma- } \\
\text { Tebessa- } \\
\text { SoukAhras }\end{array}$ & $\begin{array}{l}\text { North- } \\
\text { east } \\
\text { extreme } \\
\text { region }\end{array}$ \\
\hline 35 & $\begin{array}{c}\text { Constanti } \\
\text { ne }\end{array}$ & $\begin{array}{l}\text { (Skikda-- } \\
\text { Jijel) } 260\end{array}$ & 240 & 1,39 & $\begin{array}{c}411730 \\
9\end{array}$ & $\begin{array}{c}\text { Diverse } \\
\text { topographical } \\
\text { region } \\
\text { predominantly } \\
\text { Tell mountains }\end{array}$ & $\begin{array}{l}\text { Divese Bio- } \\
\text { climatic } \\
\text { region } \\
\text { (Humid- } \\
\text { Sub-humid) } \\
\end{array}$ & $\begin{array}{c}\text { Constantine- } \\
\text { Mila-Oum El } \\
\text { Bouaghi-Jijel- } \\
\text { Skikda }\end{array}$ & $\begin{array}{c}\text { Constan } \\
\text { t-ine } \\
\text { region }\end{array}$ \\
\hline 50 & Setif & $\begin{array}{l}\text { Nought } \\
\text { Seacoast }\end{array}$ & 115 & 1,55 & $\begin{array}{c}461718 \\
5\end{array}$ & $\begin{array}{c}\text { Diverse } \\
\text { topographical } \\
\text { region } \\
\text { predominantly } \\
\text { upper plains } \\
\end{array}$ & $\begin{array}{c}\text { Divese Bio- } \\
\text { climatic } \\
\text { regionpredom } \\
\text { inantly semi- } \\
\text { arid } \\
\end{array}$ & $\begin{array}{c}\text { SetifBatnaKhe } \\
\text { nshlaMsilaBou } \\
\text { rdj }\end{array}$ & $\begin{array}{l}\text { Plain } \\
\text { Region }\end{array}$ \\
\hline
\end{tabular}

\section{CONCLUSION}

The research work has enabled us to attain the goal of introducing new development regions, reflecting the specificity of the development reality and as a means of addressing the issue of developmental imbalances within the studied spatial unity, which is geographically, economically and socially different. According to the correlation method used in the search, we were able to draw a map that embodies the development possibilities of each region, the adopted methodology is considered a method of work, which can be utilized by the state in related matters. Nevertheless, the most important results from the paper are the following:

- The study indicated the existence of three geographically homogenous yet developmentally diverse development regions, the goal we are aiming to achieve. (The extreme north-east development region, the Constantine Development region, the development zone of the upper eastern plains). the results are exhibited in the (Figure 3 ) of development regions.

- The study results the introduce (3) different development factors derived from response variables: the first factor is associated with various variables the highest rate of variability is $29.179 \%$ followed by the second factor and associated with changes in the industrial sector and service facilities at $15.633 \%$, then the third factor which is related to an agricultural sector group and other equipment and services sectors.

- The results of the meta-analysis show that (04) groups of great importance are seen as a means of development planning process, and are increasingly important with the credibility of variables on both the quantitative and the qualitative side

- Identification of development regions according to statistical perspective (factor and cluster analysis The results of the analysis are adjusted by dropping the principles and criteria adopted in the division that are consistent with Algerian realities in different fields is a worthy process, and this is a way for the authorities to accelerate the reduction of development inequalities by focusing on backward regions by giving them greater opportunities in terms of investments and achieving the desired rates nationally or Regionally. 
- The created regions were based on a new vision by not only adhering to the results of statistical analysis, in which we faced a deficiency linked to the results of the cluster analysis where the wilayas are statistically it is not spatially homogeneous, which is contrary to the definition of the region where spatial homogeneity is required. To correct this, the work provided us with some principles until we had to remove the insufficiency and we arrive to the statistically and spatial homogeneous regions, which are the search outputs.

- Results of research work were obtained through extracting wilayas development regions in the north-east of Algeria as a means of achieving balanced development.

- Dealing with statistical methods and SPSS with a significant objectivity, especially when selecting variables related to the studied phenomenon, this is to give a more effectiveness to the program and form a comprehensive picture of the development, hence it is highly recommended to insert many variables related to financial investments or allocations, which were not available to us when collecting data.

- The study emphasizes that development is an interactive process, not a single isolated one, meaning that interaction reflects different levels of development, and is also greatly influenced by socio-economic and current factors.

- The research work focused on the Algerian north-east wilayas, (27) variables were utilized, a small number, especially regarding these subjects, is also preferable to use variables drew from (ONS) since they are derived from reality.

In the face of Algeria's economic and social trends, we are facing the challenge of reconsidering the administrative and spatial structure, through more rational and flexible policies of management furthermore to seek effective necessities that will support the new options. The choice of a new administrative link between the state and the wilaya which is the region. This latter as a framework for the overall and developmental rebalancing, i.e. correcting existing developmental imbalances.

The adoption of research outputs remains as a mechanism and a useful means of re-division of the national territory, plus the resuscitation of regional administrative institutions is an urgent necessity to complete the construction and modernization of the state; our next research project.

\section{REFERENCES}

Amer, W. (2000). Cadre d'analyse de contraste de la distribution en république arabe d'Egypte [Contraste analysis Framework the distribution of servises in the arabe republic of Égypt], Faculté Planification Régional et Urbanisme, Université Du Caire, pp. 111-132A.

Benmammar, B.H. (2003). Redéploiement de l'état et régionalisation de l'Algérie [Redéploiement of the state and regionalization of Alegria], Edition dar adib, p. 61-96.

Faye, C., Sané, B., Thiaw, I., \& Wade, C. T. (2019). Data Classification Techniques and System for Predicting Discharges in the Gambia River Basin. Analele Universităţii din Oradea, Seria Geografie, 29(2), 158-173.

Herman, G.V., Grama, V., \& Stupariu, I.M. (2016). The international organisation between globalization and regionalization. Case study: World Tourism Organization. Revista Română de Geografie Politică, 28(2), 49-59.

Herman, G.V., \& Grama, V. (2018a). Geographical aspects of space-time evolution of independent states. Revista Română de Geografie Politică, 20(2), 49-56.

Herman, G.V., Szabo-Alexi, M., Szabo-Alexi, P., Dragoş, P.F., \& Marinău, M. (2018b). The sport, vector of regionalization/globalization Case study: International Volleyball Federation (FIVB). GeoSport for Society, $8(1), 40-50$.

Kolladi, M. (1993). Cours d'analyse des données [Data analysis courses], Université de Constantine, p. 91.

Kovaçi, I., Tahiri, A., \& Bushi, F. (2020). Travel and Tourism Industry Development-The Case of Kosovo. Analele Universităţii din Oradea, Seria Geografie, 30(2), 147-156.

Laffly, D. (2000). Introduction a l'analyse factorielle des correspond [Introduction to factor analysis of correspondance], Université de pan, Laboratoire société environnement de territoire.

Lekhal, A. (1996). Base économique et rôle spatial des petites ville dans l'est algérien [Economic base and spatial rol Small city in eastren Alegria], Thèse doctorat d'Etat, université de Constantine, p. $234-248$.

Loin $n^{\circ}(87-03)$ relative a 1 amenagement du territoire, [Law related to planning territory], Journal officiel algerienne, $N^{\circ} 5$ du 28/01/1987.

Mechiche, A.M. (1997). Région + Démocratie développement, [Region + democracy = development], Éditions sidi 
mechiche elalmi, dépôt légal 1386/ 1997, ISBN 9981162116, p. 22.

Ministre de l'Equipment et de l'aménagement de territoire (MEAT) (1995). L'Algérie demain, [Alegria tomorrow], Sservice de presse universitaire ben aknoun Alegria, p. 100 -307.

Othman, M.G. (1998), Planification du développement régional, [Regional development planning], Maison al safa pour l'impression l'Edition et la distribution, p. $47-93$.

Richard, Y. (2014). Régionalisation, régionalisme et intégration régionale: concepts flous et nécessaire clarification. La Régionalisation du Monde: Construction territoriale et articulation global/local, 23-44.

Vučković, M., Đorđević, J., Jovanov, J., \& Bibić, L. (2018). Socio-economic characteristics as limiting factors of regional development. The case of Kolubara District, Republic of Serbia. Romanian Journal of Geography, 62(2), 217-223.

***(2016). Ministre des finances (M.F), Annuaire statistique algérien, [Statistical years algeria].

*** (2008). Officie National des Statistiques (O.N.S), données statistique, [statistical data], est élaboré par la direction technique chargée des statistique.

Submitted:

Octomber 10, 2020
Revised:

November 20, 2020
Accepted and published online

January 04, 2021 